TecnoLógicas

ISSN-p 0123-7799

ISSN-e 2256-5337

Vol. 23, No. 48, pp. 233-248

Mayo-agosto de 2020

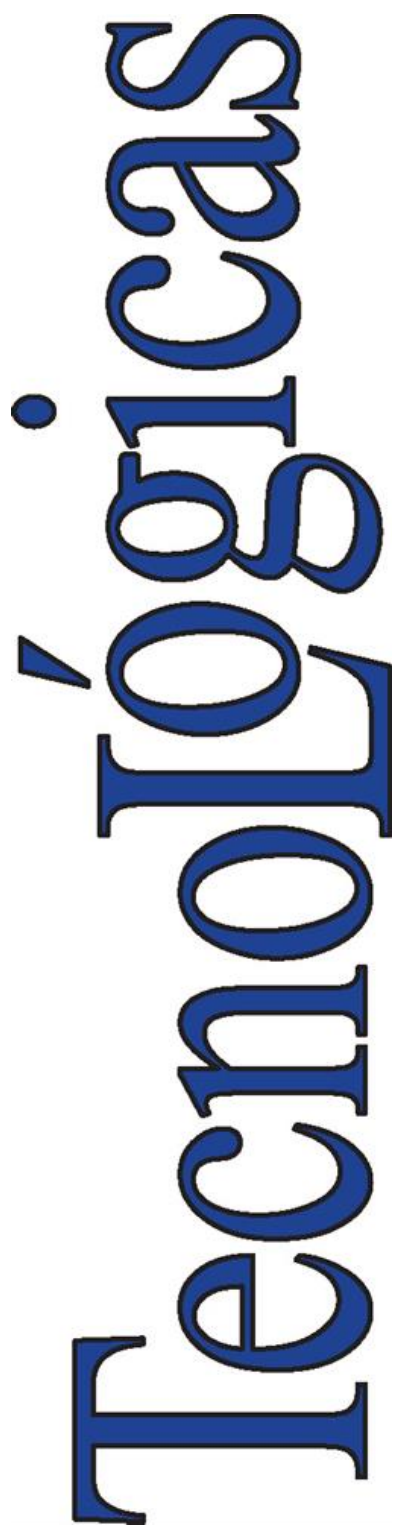

(C) Instituto Tecnológico Metropolitano Este trabajo está licenciado bajo una Licencia Internacional Creative Commons Atribución (CC BY-NC-SA)

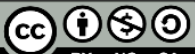

Artículo de Investigación/Research Article

\section{In-Situ Characterization of 1-Hexene Concentration with a Helium-Neon Laser in the presence of a Solid Catalyst}

\section{Caracterización in-situ de la concentración de 1-hexeno con un láser Helio-Neón en la presencia de catalizador sólido}

\author{
Juan Guillermo Lacayo (D)1, Sebastián López (D)2 \\ David Soto (D) 3 , Alejandro Molina (D) 4
}

Recibido: 30 de octubre de 2019

Aceptado: 11 de mayo de 2020

Cómo citar / How to cite

J. G. Lacayo, S. López, D. Soto, y A. Molina, "In-Situ Characterization OF 1-Hexene Concentration with a Helium-Neon Laser in the presence of a Solid Catalyst", TecnoLógicas, vol. 23, no. 48, pp. 233-248, 2020. https://doi.org/10.22430/22565337.1528

1 MSc en Ingeniería Química, Grupo de investigación Bioprocesos y Flujos reactivos, Facultad de Minas, Universidad Nacional de Colombia, Medellín- Colombia, jglacayol@unal.edu.co

2 MSc en Ingeniería Química. Grupo de investigación Bioprocesos y Flujos reactivos, Facultad de Minas, Universidad Nacional de Colombia, Medellín- Colombia, selopezgo@unal.edu.co

3 MSc en Ingeniería Química, Grupo de investigación Bioprocesos y Flujos reactivos, Facultad de Minas, Universidad Nacional de Colombia, Medellín- Colombia, dasotog@unal.edu.co

4 PhD. en Ingeniería Grupo de investigación Bioprocesos y Flujos reactivos, Facultad de Minas, Universidad Nacional de Colombia Medellín-Colombia, amolinao@unal.edu.co 


\section{Abstract}

This study provides evidence that a helium-neon (He- $\mathrm{Ne}$ ) laser operating in the Midinfrared (MIR) at a wavelength of $3.39 \mu \mathrm{m}$ can detect variations in 1-hexene concentration in the presence of a solid catalyst. The in-situ and online characterization of the concentration of 1-hexene, as an example of a hydrocarbon, is relevant to enhance the current understanding of the interaction between hydrodynamics and chemistry in different heterogeneous catalytic processes. We designed and built a laboratory-scale downer unit that enabled us to analyze heterogeneous catalytic reactions and provided optical access. The lab-scale reactor was 180-cm long, had an internal diameter of $1.3 \mathrm{~cm}$, and was made of fused quartz to allow the passage of the laser beam. 1-hexene was carefully measured, vaporized, and fed into the reactor through two inlets located at an angle of 45 degrees from the vertical descendent flow and $70 \mathrm{~cm}$ below the input of a solid catalyst and a purge flow entraining $\mathrm{N}_{2}$. A system of five heaters, which can be moved in the vertical direction to allow the passage of the laser beam, guaranteed temperatures up to $823 \mathrm{~K}$. Computational Fluid Dynamics (CFD) simulations of the hydrodynamics of the system indicated that a uniform temperature profile in the reaction section was reached after the catalyst and the feed mixed. The estimated catalyst to oil ratio and time on stream in the experiments were, respectively, 0.4 to 1.3 and $2 \mathrm{~s}$. After a correction for laser power drift, the experimental results showed a linear response of the fractional transmission to the 1-hexene concentration that was independent of temperature in the $373 \mathrm{~K}-673 \mathrm{~K}$ range. Even in the presence of a catalyst, the absorption of 1-hexene at the MIR frequency of the laser was high enough to enable the detection of 1-hexene since the fractional absorption of the absorbing path length in these experiments was close to zero $(0.013 \mathrm{~m})$ and the 1-hexene concentrations were higher than $1.254 \times 10^{-5} \mathrm{~mol} / \mathrm{cm}^{3}$. This result demonstrated the ability of the laser system to measure the concentration of 1 -hexene in the presence of a catalyst and indicates that it can be used to better decouple hydrodynamics from kinetics in heterogeneous catalytic processes.

\section{Keywords}

HeNe laser, in-situ measurements, 1-hexene, heterogeneous catalyst, Computational Fluid Dynamics.

\section{Resumen}

Se presenta evidencia de que un láser de helio-neón (He-Ne), que opera en el infrarrojo medio (MIR) a una longitud de onda de $3.39 \mu \mathrm{m}$, puede detectar variaciones de la concentración de 1-hexeno en presencia de catalizador sólido. La caracterización in situ y en línea de la concentración de 1-hexeno, un ejemplo de hidrocarburo, es importante para mejorar el entendimiento de la interacción entre la química y la hidrodinámica en procesos de reacción heterogénea. En esta investigación, se diseñó y construyó una unidad downer a escala de laboratorio. El reactor tiene una longitud de $180 \mathrm{~cm}$, un diámetro interno de 1.3 $\mathrm{cm}$ y fue fabricado en cuarzo fundido para permitir el paso del rayo láser. El 1-hexeno se dosificó, se vaporizó y se introdujo en el reactor a través de dos entradas ubicadas en un ángulo de 45 grados desde el flujo descendente vertical y $70 \mathrm{~cm}$ por debajo de la entrada de un catalizador $(0.5 \mathrm{~g} / \mathrm{s})$ y un flujo de $0.55 \mathrm{lpm}$ de purga de $\mathrm{N}_{2}$ de arrastre. Un sistema de cinco calentadores, que se puede desplazar en direccion vertical para permitir el paso del rayo láser, garantiza temperaturas de hasta $823 \mathrm{~K}$. Simulaciones de dinámica de fluidos computacional (CFD) de la hidrodinámica del sistema muestra que se alcanza un perfil de temperatura uniforme en la sección de reacción luego de la mezcla del catalizador con la alimentación. La relación estimada de catalizador a aceite y el tiempo en la corriente en los experimentos fueron de 0.4 a 1.3 y $2 \mathrm{~s}$, respectivamente. Después de la corrección de la variación de potencia del láser, los resultados experimentales mostraron una respuesta lineal de la transmisión fraccional con la concentración de 1-hexeno que era independiente de la temperatura en el rango de $373 \mathrm{~K}$ a $673 \mathrm{~K}$. Incluso en presencia de catalizador, la absorción de 1-hexeno en la frecuencia del MIR del láser utilizado en los experimentos es lo suficientemente alta como para permitir la detección de 1-hexeno ya que la absorción fraccional es cercana a cero para la longitud del camino de absorción $(0.013 \mathrm{~m})$ de estos experimentos y concentraciones de 1-hexeno superiores a $1.254 \times 10^{-5} \mathrm{~mol} / \mathrm{cm}^{3}$. La configuración experimental permitió demostrar la capacidad del sistema láser para medir la concentración de 1-hexeno incluso en presencia de un catalizador. Esto indica que es posible su uso para distinguir mejor el efecto de la hidrodinámica de la cinética en procesos de catálisis heterogénea.

\section{Palabras clave}

Láser HeNe, Mediciones In situ, 1-hexeno, Catálisis heterogéneo, Dinámica de fluidos computacional. 


\section{INTRODUCTION}

Traditionally, analytical techniques such as gas chromatography (GC), mass spectrometry (MS), or a combination of both (GC-MS) have been used to measure the aromatic and saturate contents at the outlet of catalytic cracking units that operate in refineries and to determine their global conversion [1], [2].

Interestingly, a simple concentration analysis in these setups takes more than 10 minutes, while most cracking reactions take 3 seconds or less [3]. Developing measurement techniques that operate in situ and provide real-time information may be beneficial for the study of the heterogeneous catalytic processes that take place in refineries (such as fluid catalytic cracking, FCC) and their interaction with the complex hydrodynamics of circulating fluidized beds. Real-time information may be also useful for process control and to improve process efficiency [4]-[6].

Optical techniques allow online and insitu gas sensing [7], [8]. For instance, in the field of FCC, optical-fiber probes [9] have been extensively used for particle velocity and cluster sizing measurements at atmospheric conditions [10]-[12]. While the use of different optical techniques such as Mid-Infrared (MIR) spectroscopy for the analysis of the concentration of hydrocarbons is well documented [13]-[16], the methodology to evaluate the global conversion based on the nature of the $\mathrm{C}-\mathrm{H}$ bonds present in hydrocarbons and BeerLambert's law proposed by Lopez-Zamora et al. [17] was the first applied to FCC.

The experiments in this study were conducted with a helium-neon (HeNe) laser operating at a wavenumber of 2949.85 $\mathrm{cm}^{-1}$ (3.39 $\mu \mathrm{m}$ wavelength) using 1-hexene and 1,3,5-triisopropyl benzene (TIPB) as model compounds. A Riser Simulator ${ }^{\circledR}$ operating at $823 \mathrm{~K}$, a ratio of catalyst to oil $(\mathrm{CTO})=2.5$, and a time on stream $($ TOS $)=7$ sec were used to validate the method.
A fiber optic sensor was employed to locate the laser beam aiming at the external annular space (downflow zone) of the reactor, without the presence of particles.

In the peer-reviewed literature in this field, no other optical diagnostic method has been applied to characterize the FCC reaction or other reactions in cracking systems. The evaluation of the effect of catalyst particles on the ability of the MIR described in [17] is an important step towards the widespread application of this technique for the characterization of FCC systems.

While different laboratory-scale reactors have been widely used for kinetic and catalysts evaluation [18]-[29], in their original configurations it is difficult to include an optical setup to perform in-situ and real-time measurements in the presence of a catalyst. In this study, we report the design and construction of such a setup. The equipment was conceived as a testing tool for optical techniques that can be used in a wide range of operating conditions. Our setup was used to validate the operation of the optical setup described by Lopez-Zamora et al. [17] for the evaluation of the 1-hexene concentration in the presence of an equilibrated FCC catalyst.

\section{EXPERIMENTS DEVELOPMENT}

Fig. 1 presents a simplified process flow diagram of an experimental downer setup. In it, a heater increases the catalyst temperature before it comes into contact with the feed at the upper part of the reactor. The temperature in the catalyst heater is set in such a way that the catalyst stream heats the feed to a previously defined reaction temperature; the reaction continues while both phases are flowing downwards. Finally, products and spent catalyst are separated. 
In-Situ Characterization OF 1-Hexene Concentration with a Helium-Neon Laser In Thepresence of a Solid Catalyst

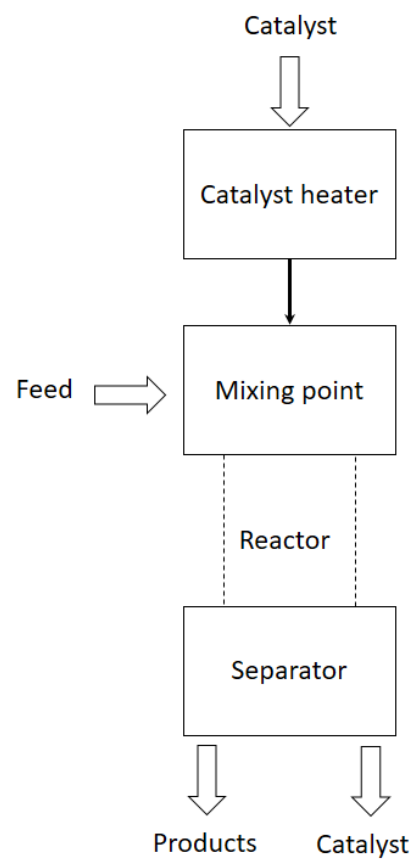

Fig. 1. Simplified process flow diagram of the experimental setup that represents the downer reactor used for the study of heterogeneous catalytic reactions.

Source: Created by the authors.

A critical issue in the design of an experimental system for the analysis of heterogeneous catalytic reactions is the need to guarantee that the temperature profile in the reactor stays at a nominal constant value, despite the fact that the catalyst and the feed enter at different temperatures and that the residence time in the reactor is short. We carried out measurements as well as Computational Fluid Dynamic (CFD) simulations to validate the temperature profile in the reactor.

\subsection{CFD simulation}

The CFD simulation of the downer reactor considered the three spatial dimensions and was developed using an Eulerian-Lagrangian approach where the fluid (gas) is treated as a continuous phase while the dispersed phase (catalyst) is solved by tracking a large number of particles. The commercial CFD software ANSYS Fluent V15.0 was used to discretize and solve the Navier-Stokes equations of continuity, momentum, species, and energy transfer. The equations considered in our simulations have been widely reported and can be consulted in several references [30]-[32].

The simulation domain was divided into two zones. The first domain considered the particle-heating zone, where the particles were heated from ambient temperature to a nominal temperature.

The actual process conditions are described below. A second zone included the entrance of the feed stream (FS) into the reactor zone.

A tetrahedral mesh was used for both zones. The particle-heating zone had $6 \times 10^{5}$ elements with a mean aspect ratio of 0.88 . The nitrogen and particle inlet were represented as a Mass flow inlet boundary condition (BC). For the walls, a no-slip condition was considered. A Pressure outlet BC represented the exit of the particle heating zone. 
The reaction zone considered $1.8 \times 10^{6}$ tetrahedral elements with a mean aspect ratio of 0.76 . More elements were required to model the reaction zone than the heating zone as the former is longer and more refinement is required to capture the flow from the inlet of the FS. While meshsize independence analysis is desirable to support a CFD calculation, computational and time limitations made such analysis unfeasible in this study. Nevertheless, an adequate agreement between experiments and simulations, as presented below, was considered enough to support the simple CFD conclusion in this paper.

Fig. 2 shows the top of the reaction zone where the refinement is evident; it also presents the BCs used in this simulation.

The inlet of the nitrogen and particles coming from the heating zone to the reaction zone was represented as a Mass flow inlet $\mathrm{BC}$ entering at the exit temperature obtained in the simulation of the heating zone.

The FS entered through two holes at a $45^{\circ}$ angle on the vertical axis.

The FS input was represented by a Mass flow inlet BC. For the reactor, a Wall
$\mathrm{BC}$ with a no-slip condition and a constant temperature was considered. A Pressure outlet $\mathrm{BC}$ represented the exit flow of the reactor. To decrease the computational time, the simulation did not consider heat transfer through radiation in the reaction zone. The acceptable agreement between experiments and modelling, as presented below, indicates that neglecting radiation does not significantly influence the conclusions obtained from the simulations

The CFD simulation was simplified by neglecting the interaction between the continuous (gas) and discrete (particle) phases. In this way, the solution of the dispersed phase considers the momentum and energy contribution from the continuous phase but not vice versa [33].

To represent the reaction, the simulation considered a pseudohomogeneous reaction in the continuous phase and inert catalyst particles. To study heat transfer, the effect of the reactions is important because the system is accelerated due to the increase in volume caused by the cracking reactions [34]. The chemical reaction mechanism was that reported by [35].

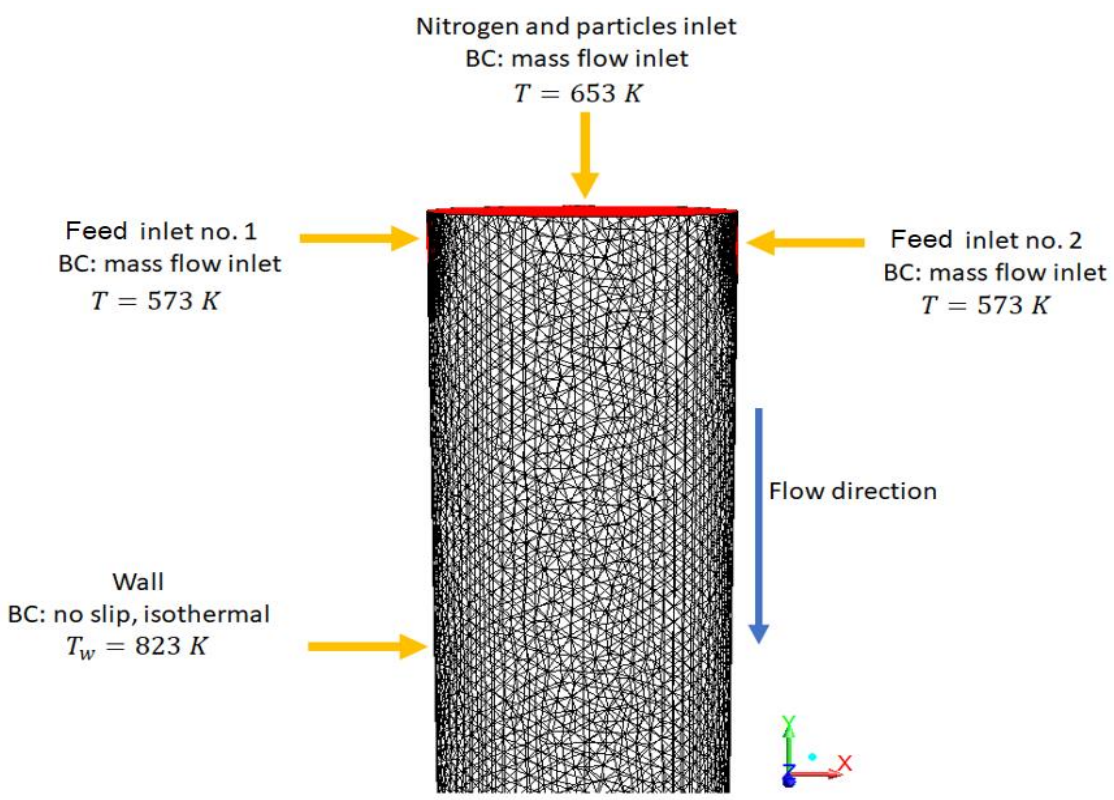

Fig. 2. Lateral view of the mesh used for the simulation of the top of the reaction zone Source: Created by the authors. 
The CFD simulation required knowledge about properties related to heat transfer in the gas phase as well as the solution of the momentum equation. The thermal conductivity $\left(\kappa_{N_{2}}\right)$, specific heat $\left(C p_{N_{2}}\right)$, and dynamic viscosity $\left(\mu_{N_{2}}\right)$ of nitrogen were calculated using a polynomial approximation that was a function of the gas temperature $\left(f\left(T_{g}\right)=\mathrm{A}_{1}\right.$ $\left.+\mathrm{A}_{2} \cdot \mathrm{T}_{\mathrm{g}}+\mathrm{A}_{3} \cdot \mathrm{T}_{\mathrm{g}}{ }^{2}+\mathrm{A}_{4} \cdot \mathrm{T}_{\mathrm{g}}{ }^{3}+\mathrm{A}_{5} \cdot \mathrm{T}_{\mathrm{g}}{ }^{4}\right)$. Table 1 summarizes the polynomial coefficients.

The ideal gas law was used to calculate density. While experiments, as discussed below, were conducted with 1-hexene, in the CFD simulation, the properties were those of TIPB at $823 \mathrm{~K}(\mathrm{k}=0.05 \mathrm{~J} / \mathrm{s} \cdot \mathrm{m} \mathrm{K}$, $\mathrm{Cp}=3000 \mathrm{~J} / \mathrm{kg} \cdot \mathrm{K}$, and $\mu=1.4 \times 10^{-5}$ $\mathrm{kg} / \mathrm{ms}[36])$.

TPIB is a hydrocarbon typically used as a surrogate in refinery reactions whose kinetic parameters are publicly available.
While some minor changes in the simulation are expected with 1-hexene, they should not affect the conclusions in this paper. In the reaction zone, all properties were calculated by a massweighted mixing law. For the catalyst, a mean diameter of $8.46 \times 10^{-5} \mathrm{~m}$, a catalyst density of $1525 \mathrm{~kg} / \mathrm{m}^{3}$, and a particle specific heat capacity of $1090 \mathrm{~J} / \mathrm{kg} \cdot \mathrm{K}$ [38] were considered. The particle density $\left(\rho_{\mathrm{p}}\right)$ and diameter are similar to those in other studies [39], [40]. The dimensions of the reaction zone are described below.

The emissivity $\left(\varepsilon_{\mathrm{w}}\right)$ was 0.6 , a value that corresponds to that of $3-\mathrm{mm}$ thick fused quartz at 800-900 K [41]. The MorsiAlexander drag model [42] for a spherical particle was implemented. The models relevant to the CFD simulation are listed in Table 2 [43].

Table 1. Coefficients used to compute the physical properties of nitrogen

\begin{tabular}{|c|c|c|c|c|c|}
\hline Property & $\mathbf{A}_{1}$ & $\mathbf{A}_{2}$ & $\mathbf{A}_{3}$ & $\mathbf{A}_{4}$ & $\mathbf{A}_{5}$ \\
\hline$\kappa_{N_{2}}\left(\frac{J}{s m K}\right)$ & $4.73 \times 10^{-3}$ & $7.27 \times 10^{-5}$ & $-1.12 \times 10^{-8}$ & $1.45 \times 10^{-12}$ & $-7.87 \times 10^{-17}$ \\
\hline$C p_{N_{2}}\left(\frac{J}{k g K}\right)$ & $9.79 \times 10^{2}$ & $4.17 \times 10^{-1}$ & $-1.17 \times 10^{-3}$ & $1.67 \times 10^{-6}$ & $-7.25 \times 10^{-10}$ \\
\hline$\mu_{N_{2}}\left(\frac{k g}{m s}\right)$ & $7.47 \times 10^{-6}$ & $4.08 \times 10^{-8}$ & $-8.24 \times 10^{-12}$ & $1.31 \times 10^{-15}$ & $-8.17 \times 10^{-20}$ \\
\hline
\end{tabular}

Table 2. Models used in the CFD simulation Source: Created by the author.

\begin{tabular}{ll}
\hline Models & Method \\
\hline Multiphase & Euler-Lagrange \\
Solver & Pressure-based steady-state \\
Turbulence & K- $\varepsilon$ model \\
Discrete phase model & Activated, inert particles \\
Pressure velocity coupling scheme & Phase-coupled SIMPLE \\
Residual convergence criteria & $1 \times 10^{-3}$, energy $1 \times 10^{-6}$ \\
Discretization scheme & First-order upwind \\
Gas density & Ideal gas \\
Species & Species transport \\
Drag model & Morsi-Alexander \\
\hline
\end{tabular}




\subsection{Lab-scale downer}

Fig. 3 is a schematic representation of the experimental setup that includes four zones: (1) Evaporation, (2) Particle heating, (3) Reaction, and (4) Separation. In the Evaporation zone (No. 1 in Figure 3), a precision syringe pump (New Era Pump Systems NE-8000 model) with a 200-ml stainless-steel syringe (partially filled to about $140 \mathrm{ml}$ ) controlled the rate of injection of the feed, 1-hexene $\left(\mathrm{C}_{6} \mathrm{H}_{12}, 84.16\right.$ $\mathrm{g} / \mathrm{mol}$, boiling point $=336 \mathrm{~K})$, through a resistance-heated steel cylinder $(0.12-\mathrm{m}$ length and $0.025-\mathrm{m}$ diameter) with a dedicated temperature control and packed with Ottawa sand (particle diameter, between $0.85 \mathrm{~mm}$ and $1 \mathrm{~mm}$ ). The experiments reported here were conducted at feed rates from 0.6 to $2 \mathrm{~cm}^{3} / \mathrm{min}$ of liquid 1-hexene.

Nitrogen was flown (0.42 slpm, standard conditions were considered as $293 \mathrm{~K}$ and $101325 \mathrm{~Pa}$ ) through the system initially to purge the evaporator and, later, to help entrain the evaporated feed.

Two stainless-steel hypodermic tubes transported the $\mathrm{N}_{2} /$ feed stream into the reactor. The reactor was a clear fused quartz tube $(0.013 \mathrm{~m} \mathrm{ID} \times 0.016 \mathrm{~m}$ OD $\times$ $1.80 \mathrm{~m}$ long) with two ports located at $180^{\circ}$ on the reactor surface $0.70 \mathrm{~m}$ from the catalyst inlet. These ports, used for the feed entrance, were tilted $45^{\circ}$ from the vertical axis, in the direction of the flow.

The catalyst flow was controlled by a volumetric screw feeder (Schenck Process AccuRate $106 \mathrm{M}$ ) that was calibrated for a catalyst mass flow between $7.5 \mathrm{~g} / \mathrm{min}$ and $105.9 \mathrm{~g} / \mathrm{min}$. In the experiments, the catalyst flow was $30 \mathrm{~g} / \mathrm{min}$, which, for the feed flow described above, yields a catalyst to oil ratio of 0.4 to 1.25 . Equilibrated catalyst particles between 53 and $106 \mu \mathrm{m}$ were used in the experiments. A tube furnace (H1 in Fig. 3) of $0.45 \mathrm{~m}$ in length, located in the particle heating zone (Zone 2 in Figure 3) before the inlet of the feed ports, heated the catalyst particles up to $873 \mathrm{~K}$. Nitrogen entered the quartz tube $(0.13 \mathrm{slpm})$ and the upper part of the feeder hopper $(0.035 \mathrm{slpm})$ to neutralize the buoyancy effect of the hot gases in the reactor and purge the catalyst from oxygen, respectively. The time on stream of the downer considering the feed and nitrogen flows was estimated at $2 \mathrm{~s}$.

Depending on the operating conditions, cracking reactions can take place throughout the lower part of the fused quartz tubing, i.e., from the feed entrance where the evaporated feed, the catalyst, and nitrogen mix, to the fused quartz end, approximately $1.10 \mathrm{~m}$ below.

This is the Reaction zone, No. 3 in Fig. 3. Four additional tube furnaces with different lengths $(0.30 \mathrm{~m}, 0.25 \mathrm{~m}, 0.20 \mathrm{~m}$, and $0.20 \mathrm{~m}$ ), individual temperature controls, and that can be moved in the vertical position to allow optical access keep the Reaction zone at a maximum reaction temperature of $823 \mathrm{~K}$. The temperature control used type $\mathrm{K}$ thermocouples located $5 \mathrm{~mm}$ away from the exterior of the quartz tube.

At the end of the Reaction zone, a separation cyclone removes spent catalyst from the gas reaction products, a flexible stainless steel hose is connected from the cyclone's gas outlet to an exhaust hood, and the catalyst is received in a collection box with 4.5 L of capacity (No. 4 in Fig. 3).

A data acquisition system continuously logged the temperature at the outlet of the Evaporation zone (TI-1 in Fig. 3), the temperature of the five furnaces (TI-2 to TI-6 in Fig. 3), and relevant data from the optical measurements. 


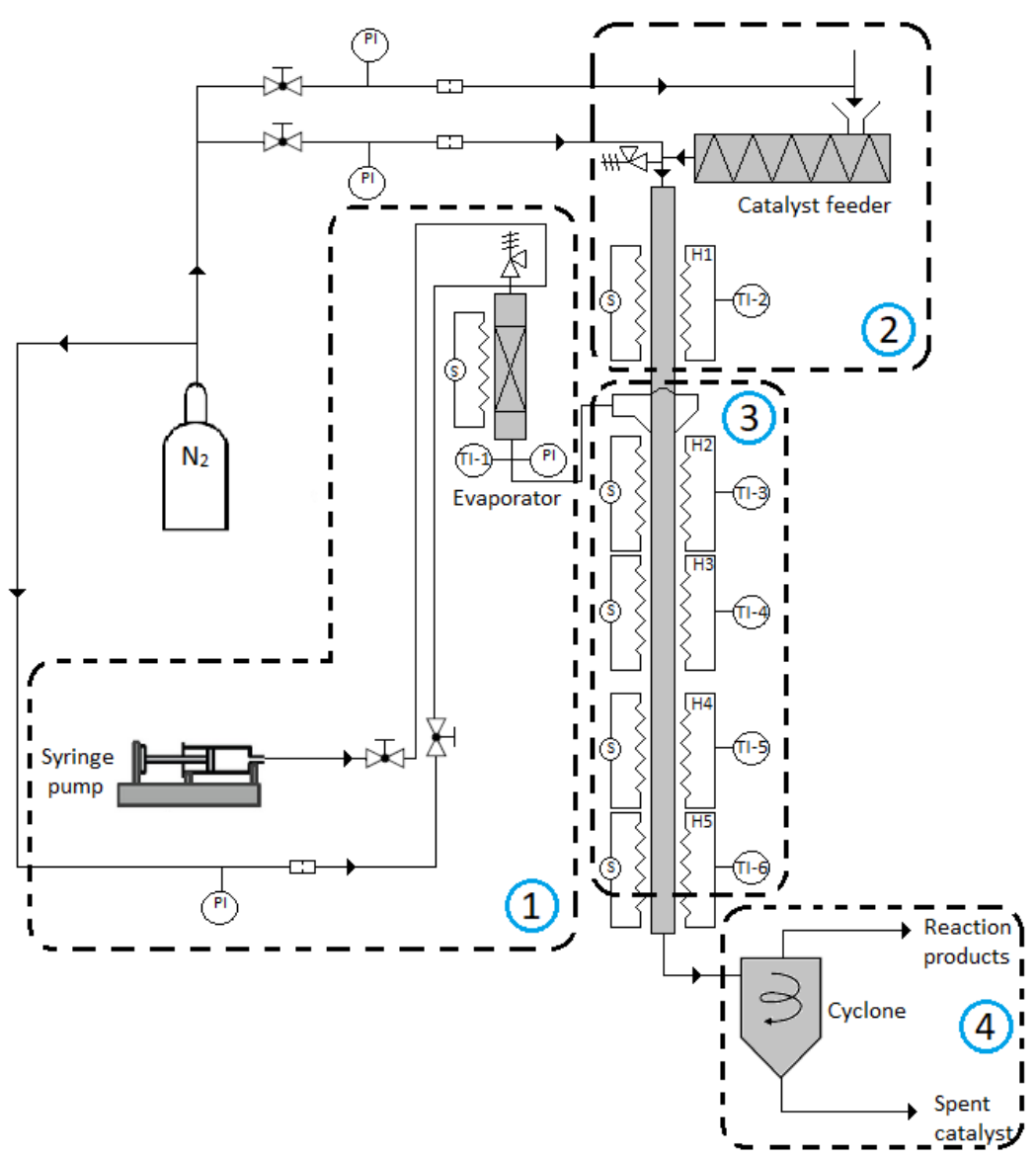

Fig. 3. Experimental setup: (1) Evaporation zone, (2) Particle heating zone, (3) Reaction zone, and (4) Separation zone. Source: Created by the authors.

\subsection{Optical setup}

As previously mentioned, Lopez-Zamora et al. [17] demonstrated the use of a $\mathrm{HeNe}$ laser operating in the MIR for monitoring the progress of a FCC reaction. In the present study, the same optical setup proposed by Lopez-Zamora et al. was adapted to operate in the reactor in Fig. 3 and evaluate the effect of particle flow. Other authors [17] have reported details of the spectroscopic information of 1 -hexene in the MIR region.

Fig. 4 is a picture of the optical setup operating in the quartz reactor.

The optical setup includes three parts: (1) a continuously operating $\mathrm{HeNe}$ laser (Research Electro Optics, Inc.) with a wave number of $2949.9 \quad \mathrm{~cm}^{-1} \quad(3.39 \mu \mathrm{m}$ wavelength), a beam diameter of $2.02 \mathrm{~mm}$, and a maximum output power of $7 \mathrm{~mW}$; (2) an optical chopper that can reach a frequency up to $1000 \mathrm{~Hz}$; and (3) a PDA20H (-EC) PbS photodetector (Thorlabs) with a detection wavelength range between $1.5 \mu \mathrm{m}$ and $4.8 \mu \mathrm{m}$. There is a $0.45-\mathrm{m}$ distance between the $\mathrm{He}-\mathrm{Ne}$ laser and the photodetector, but the actual absorbing path length is equal to the reactor's inner diameter, i.e., $0.013 \mathrm{~m}$.

The changes in concentration of the feed stream along the reactor were related to changes in the intensity of the laser beam according to Beer-Lambert law (1) [44]:

$$
-\ln \frac{I}{I_{0}}=\sigma_{\lambda, i}(T, P) n_{i} L=\alpha_{i}
$$



Catalyst

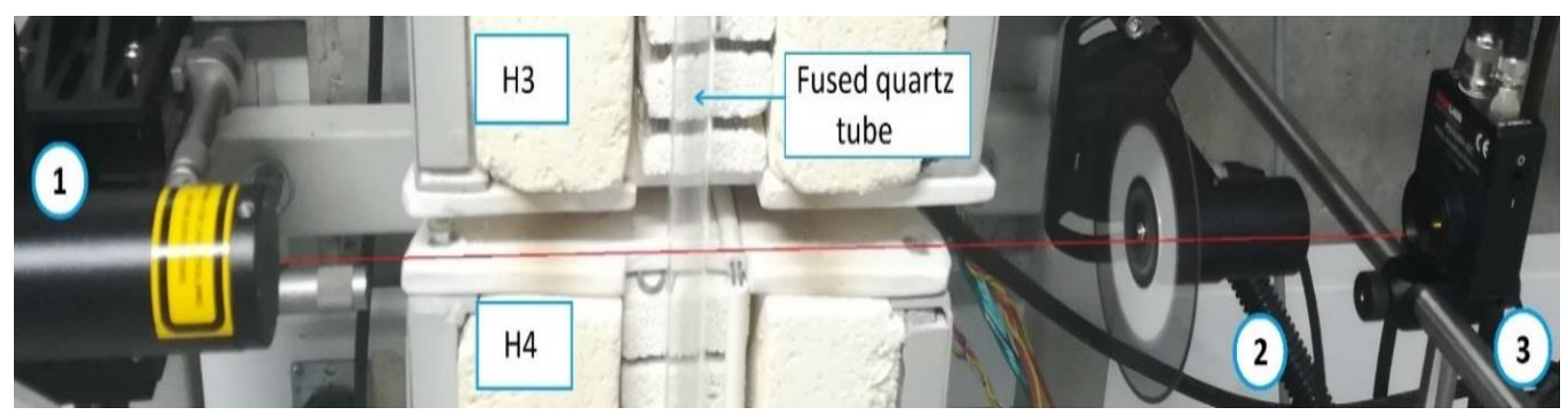

Fig. 4. Photo of the optical setup adapted to the reactor: (1) He-Ne Laser, (2) Optical chopper, and (3) Photodetector. The picture shows a section between H3 and H4 as labelled in Fig. 3

Source: Created by the authors.

where $I_{0}$ and $I$ are, respectively, the intensity of the radiation before and after the interaction of the laser beam with the medium; $\sigma_{\lambda, i}$ is the absorption cross-section of species $i$ that depends on the temperature and pressure; $n_{i}$, the concentration of species $i$; and $\mathrm{L}$, the path length. $\alpha_{i}$ is known as absorbance and, as (1) states, for a constant temperature, pressure, and path length, the absorbance should be proportional to the concentration of species $i$.The previous statement has one condition: it assumes that, for the catalytic cracking of one species (as is the case in this study), any interference of the products at the specific wavelength of the experiments is negligible. The results of Lopez-Zamora et al. [17] suggest that this is the case.

During the experiments, a significant and not deliberate power drift in the HeNe laser was observed. This drift was not documented in [17]; however, such behaviour was previously reported by Klingbeil [45], who implemented a beam splitter and a reference detector to correct for the effect of the laser power drift. While the setup by Klingbeil [45] clearly mitigates any problem caused by the laser beam drift, space constraints made the use of a second photodetector difficult. The correction of the laser drift was, nevertheless, accomplished by a careful averaging and iteration procedure where feed injection was interrupted in a periodic fashion so that the variation in $I_{0}$ during the experiment could be documented.

\section{RESULTS}

Fig. 5 compares the gas temperature profile measured along the reactor with the CFD predictions. The experimental data were obtained at a nominal temperature of $823 \mathrm{~K}$ in the reaction zone, when particles and gas were flowing at the values described in the experimental section.

Although there are differences between the CFD simulations and the experiments, particularly at the reactor's inlet and outlet, the agreement is acceptable in the Reaction zone, where the optical measurements were taken and which was the focus of this analysis.

Most importantly, the measurements as well as the simulations indicate that a relatively flat profile can be obtained after the feed enters the reactor and the temperature significantly falls at around $0.6 \mathrm{~m}$. There is some uncertainty in the measurements between $1.1 \mathrm{~m}$ and $1.3 \mathrm{~m}$, when using a long thermocouple became difficult. While the results in Fig. 5 were obtained at a nominal temperature of 823 $\mathrm{K}$, a similar profile is expected in the lower temperature range ( $373 \mathrm{~K}$ to $673 \mathrm{~K}$ ) where the optical measurements were performed. 


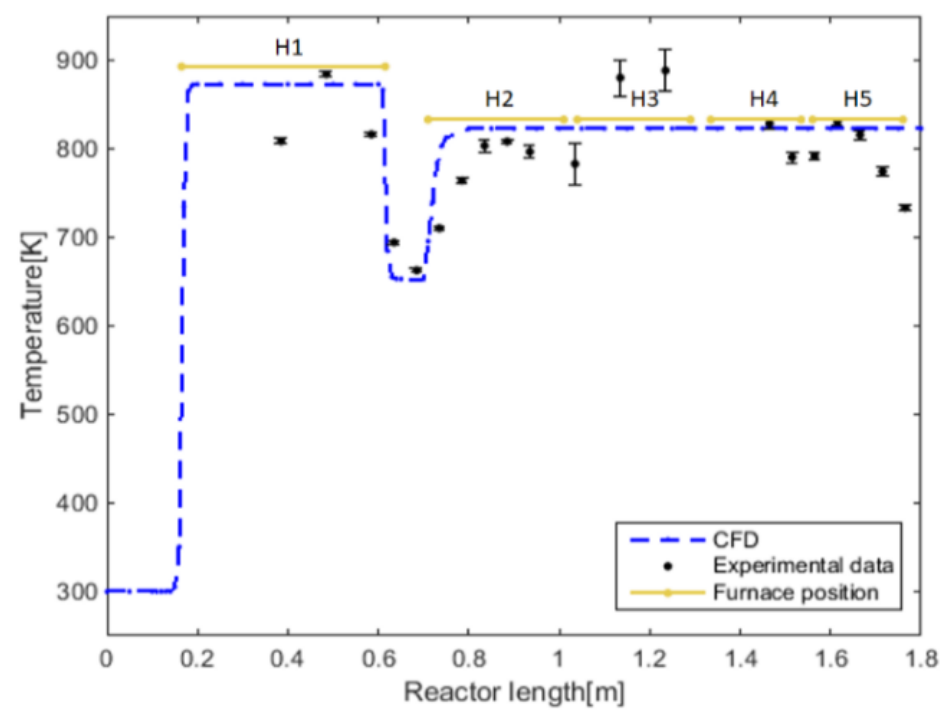

Fig. 5. Comparison of the temperature profiles along the reactor predicted by the CFD model and measured in the experiments. Error bars represent one standard deviation after three measurements Source: Created by the authors.

\subsection{Correction of the Optical Signal because of Laser Power Drift}

Fig. 6 presents evidence of the laser power drift when the distance between the laser and the photodetector was $5 \mathrm{~cm}$ and only the optical chopper was between them. After two hours of laser operation (7200 s), the fluctuations in laser intensity decreased over time but were still very intense; furthermore, there was no clear pattern. The results in Figure 6 were observed in different opportunities and could not be related to any other variable in the lab or the experiment.

To correct the signal for the laser power drift documented in Fig. 6, the experiments incorporated an iterative injection of feed and $\mathrm{N}_{2}$. Basically, a roughly 2-min feed injection was alternated with a 2-min injection of $\mathrm{N}_{2}$ with a volumetric flow equivalent to the feed flow. While $I$ was recorded when the feed was flowing, $I_{0}$ was recorded in the presence of $\mathrm{N}_{2}$. Fig. 7 illustrates the detector output during the experiments.

The uneven numbers $(1,3,5,7$, and 9), i.e., zones with higher voltage, indicate periods of time when only nitrogen and catalyst were flowing. Even numbers $(2,4$, 6 , and 8) represent periods of time when the feed (1-hexene) was injected and $\mathrm{N}_{2}$ injection stopped, always in the presence of particles. While the high-frequency peaks and valleys in the signal were caused by the detection of particles passing through the laser signal, the average signal between each section also changed because of the laser drift. As some disruption can be expected when the flow is switched from $\mathrm{N}_{2}$ to the feed and vice-versa, the following procedure was applied to obtain an average laser signal in each zone. The time at which the highest value of intensity during $\mathrm{N}_{2}$ Injection $i$ takes place was determined.

Then, the intensity data 15 seconds before and 15 seconds after that maximum were averaged.

This averaging process was repeated for $\mathrm{N}_{2}$ injection $i+2$ so that a total of $60 \mathrm{~s}$ was recorded. The average intensity value of these $60 \mathrm{~s}$ was the value of $I_{0}$ used to compute $I / I_{0}$ for feed Injection $i+1$.

$I$ was then simply calculated as the average signal $60 \mathrm{~s}$ after the feed injection had started. $I / I_{0}$ for feed Injection $i+1$ 
was then calculated as the ratio of the average values of $I 0$, and $I$ was computed as previously described.

\subsection{Optical measurements}

Fig. 8 presents the variation in fractional transmission with the molar fraction of 1-hexene with and without particles and at different temperatures.
As the molar fraction of 1-hexene increases, $I / I_{0}$ decreases because the amount of absorbed light is higher.

Interestingly, at $373 \mathrm{~K}$ and in the absence of a catalyst, when the molar fraction is only $0.45, I / I_{0}$ is already almost 0 , which indicates the high sensitivity of the optical system to the concentration of 1-hexene.

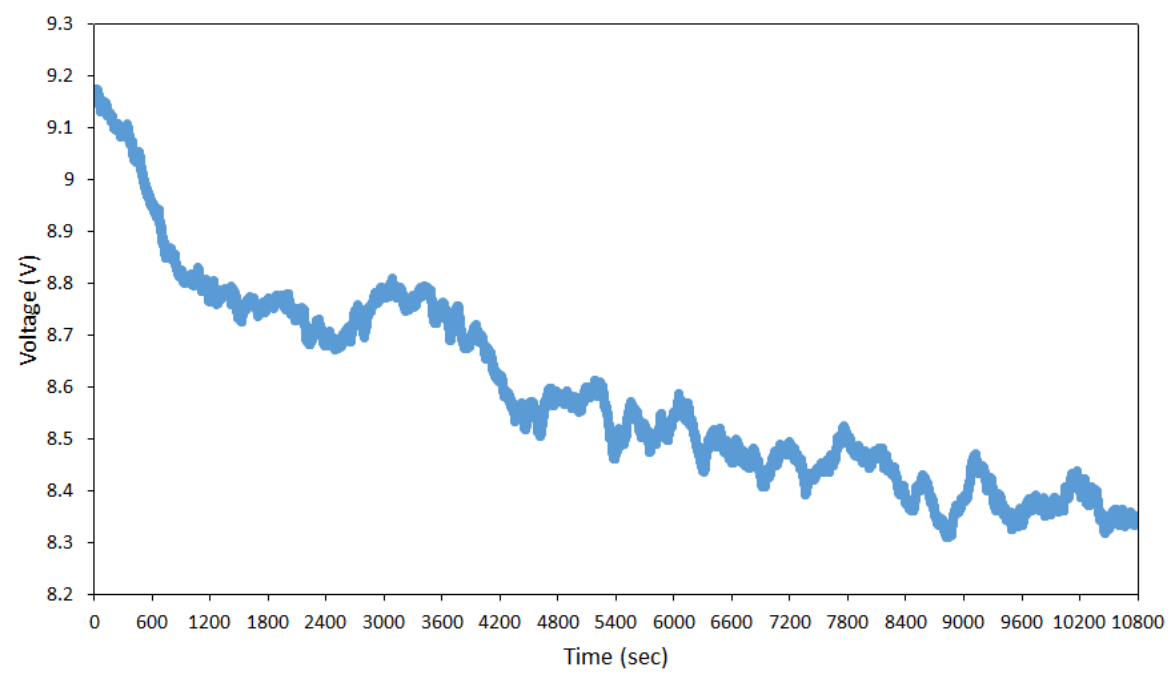

Fig. 6. Variation in laser intensity over time. Only the chopper was placed between the laser and the detector Source: Created by the authors.

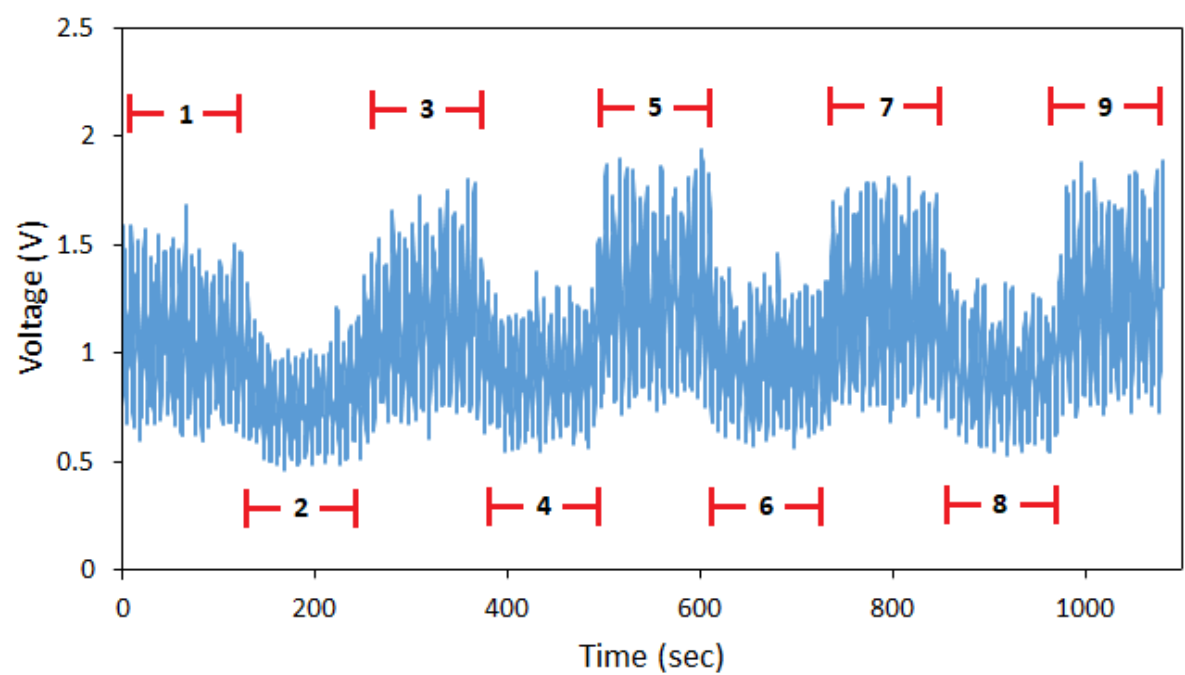

Fig. 7. Typical variation of laser intensity over time in an experiment with catalyst and 1-hexene. Uneven numbers indicate an injection of $\mathrm{N}_{2}$; even numbers, an injection of 1-hexene Source: Created by the authors. 


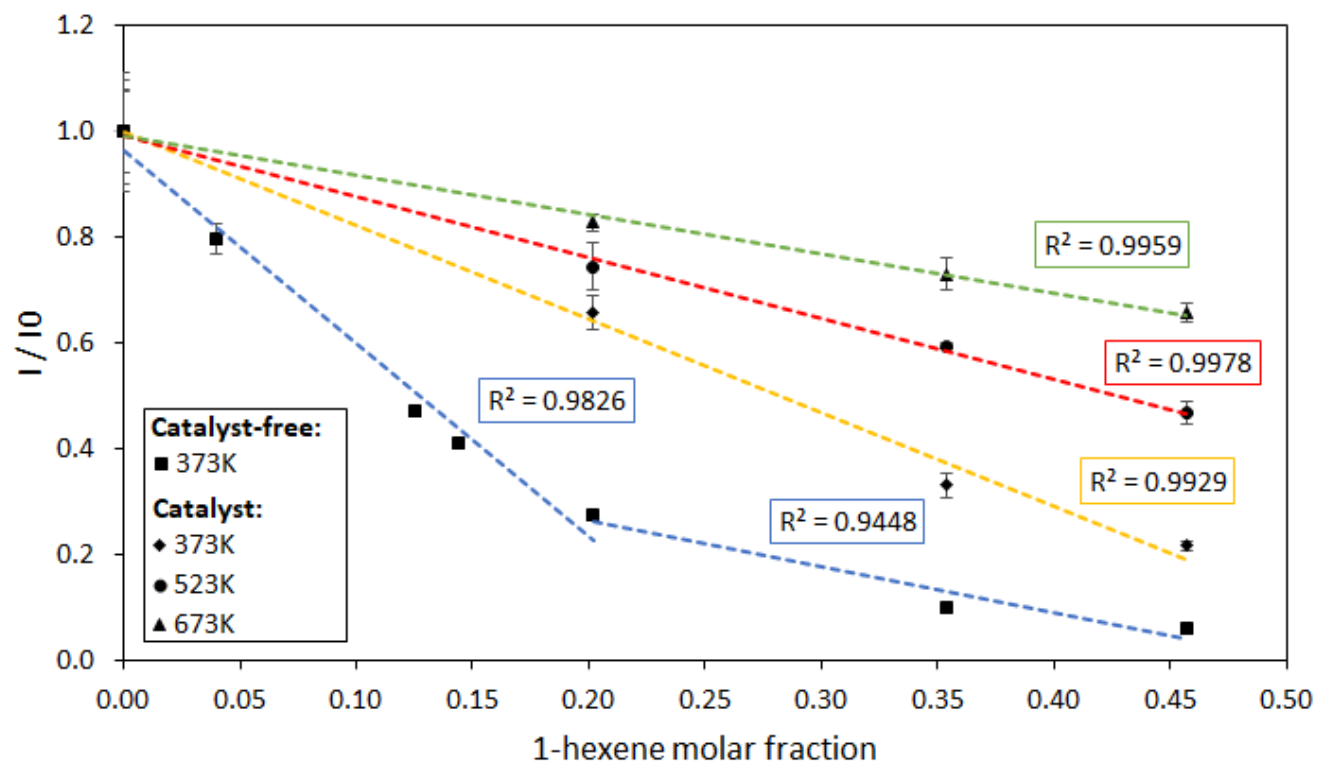

Fig. 8. Variation in fractional transmission (I/I0) as a function of the molar fraction of 1-hexene at different temperatures and in the presence and absence of a catalyst Source: Created by the authors.

At the same temperature and without a catalyst, the variation of $I / I_{0}$ with the molar fraction of 1-hexene indicates that, when the molar fraction of 1 -hexene is higher than 0.2 , the system does not obey Beer-Lambert's law, i.e., $I / I_{0}$ does not linearly vary with the concentration of 1 hexene. The nonlinearity of BeerLambert's law in concentrations higher than $10 \mathrm{mM}$ has been previously reported [46].

In turn, a linear trend was obtained when the variation of $I / I_{0}$ with the molar fraction of 1-hexene was evaluated at the same temperature $(373 \mathrm{~K})$ but in the presence of an equilibrated catalyst. The error bars of catalyst-laden experiments are larger than those of the catalyst-free trials, as one would expect given the random noise that the particle flow causes.

Furthermore, the value of $I / I_{0}$, at the same molar fraction of 1 -hexene, increased.

This result was somehow unexpected as light scattering should decrease the value of $\mathrm{I}_{0}$ in a magnitude similar to the reduction in $I$ because both depend on the number of particles flowing in the system.

One possible explanation for the increase in $I / I_{0}$ in the presence of the catalyst is the absorption of 1-hexene in the catalyst. 1-hexene absorption would decrease the amount of 1-hexene present in the homogeneous phase and, therefore, the value of $i$ would be higher in the presence of a catalyst. Nevertheless, the results at $373 \mathrm{~K}$ in the presence and absence of a catalyst are encouraging as they indicate that the measurement of 1 hexene in the reactor in the presence of a catalyst is possible and that BeerLambert's law can be used to estimate the 1-hexene concentration in the range of molar fractions in Fig. 8.

In the experiments at higher temperatures in Fig. 8 (all of them in the presence of a catalyst), it is evident that, at a given value of 1-hexene, fractional transmission increases as molar concentration increases. This was expected because the higher the temperature, the lower the molar concentration of 1- hexene.

Fig. 9 presents the same data as Fig. 8, but this time the 1-hexene concentration on the $\mathrm{x}$-axis is expressed as a molar concentration instead of a molar fraction. 


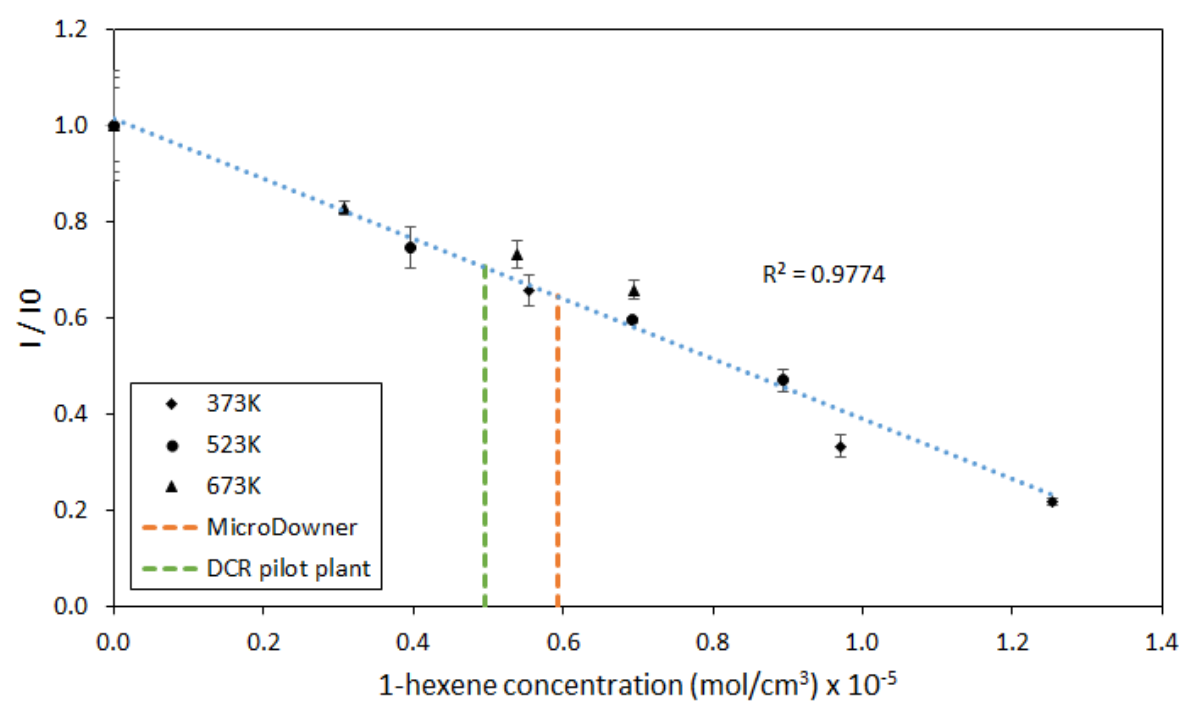

Fig. 9. Fractional transmission at different 1-hexene concentrations Source: Created by the authors.

Clearly, all the temperature lines collapse into a single line. This result indicates that, even in the presence of catalyst particles, this method could track the conversion of 1-hexene in a temperature range relevant for certain refinery processes $(673 \mathrm{~K})$. Although the absorption cross section of 1-hexene depends on temperature, in the range evaluated in this study, that dependence was low, an observation that further supports the potential application of this laser technique for the evaluation of the conversion of hydrocarbons during refinery processes.

\section{CONCLUSIONS}

As demonstrated by CFD simulation and experimental measurements, the laboratory-scale downer unit that allows optical access used in these experiments can operate in conditions where heterogeneous catalytic reactions take place. The optical setup described by Lopez-Zamora et al. [17], which includes a He-Ne laser operating at $3.39 \mu \mathrm{m}$, presents a significant drift that can be corrected without the need for a beam splitter and a reference detector if the experiments can alternate between a non-absorbing species (such as $\mathrm{N}_{2}$ ) and the feed (1-hexene in our experiments).

The absorption of 1-hexene at the MIR frequency of the laser used in the experiments was high. In fact, the fractional absorption of the absorbing path length was close to zero $(0.013 \mathrm{~m})$ at 1 hexene concentrations higher than $1.254 \mathrm{x}$ $10^{-5} \mathrm{~mol} / \mathrm{cm}^{3}$. Nevertheless, in the temperature range between $373 \mathrm{~K}$ and 673 $\mathrm{K}$, even in the presence of a catalyst, there was a linear response of the fractional absorption as a function of the 1-hexene molar fraction. It even seems possible to use a single calibration curve to determine the 1-hexene concentration for all the temperature and concentration ranges in this study. The results indicate that these systems can be confidently used for in-situ and real-time characterization of the progress of solid catalytic reactions.

\section{ACKNOWLEDGMENTS}

Major financial support for this research was provided by the Colombian Administrative Department of Science, 
Technology and Innovation (Departamento Administrativo de Ciencia, Tecnología e Innovación, Colciencias) and ECOPETROL under Contract RC 0423-2013.

\section{REFERENCES}

[1] H. Lasa and D. Kraemer, "Novel Techniques for FCC Catalyst Selection and Kinetic Modelling," in Chemical Reactor Technology for Environmentally Safe Reactors and Products, Dordrecht: Springer Netherlands, 1992, pp. 71-131. https://doi.org/10.1007/978-94-011-2747-9_5

[2] C. I. C. Pinheiro et al., "Fluid Catalytic Cracking (FCC) Process Modeling, Simulation, and Control," Ind. Eng. Chem. Res., vol. 51, no. 1, pp. 1-29, Nov. 2011. https://doi.org/10.1021/ie200743c

[3] R. Sadeghbeigi, Fluid catalytic cracking handbook: An expert guide to the practical operation, design, and optimization of FCC units. Oxford, UK: Elsevier, 2012. Available: URL

[4] H. Copete-López and S. Sánchez-Acevedo, "An Approach to Optimal Control of the Combustion System in a Reverberatory Furnace," TecnoLógicas, no. 23, pp. 13-29, Dec. 2009.

https://doi.org/10.22430/22565337.233

[5] R. Ríos, C. A. Ramos-Paja, and J. J. Espinosa, "A control system for reducing the hydrogen consumption of PEM fuel cells under parametric uncertainties," TecnoLógicas, vol. 19, no. 37, pp. 45-59, Jun. 2016. https://doi.org/10.22430/22565337.59

[6] I. D. Ramírez-Rivas, "Anaerobic digestion modeling: from one to several bacterial populations," TecnoLógicas, no. 31, pp. 181201, Nov. 2013.

https://doi.org/10.22430/22565337.117

[7] J. C. Briñez-De León, A. Restrepo-Martínez, and F. López-Giraldo, "Pixels Intensity Evolution to Describe the Plastic Films Deformation," TecnoLógicas, SE-Computer science, pp. 695-707, Nov. 2013. https://doi.org/10.22430/22565337.397

[8] E. Reyes-Vera, D. E. Senior, J. M. LunaRivera, and F. E. López-Giraldo, "Advances in electromagnetic applications and communications," TecnoLógicas, vol. 21, no. 43, pp. 9-13, Sep. 2018. https://doi.org/10.22430/22565337.1052

[9] V. H. Aristizabal, "Introducción a la Tecnología de Fibras Ópticas y Análisis numérico de la propagación de la luz en fibras micro-estructuradas" TecnoLógicas, no. 19, pp. 141-166, Dec. 2007. https://doi.org/10.22430/22565337.508

[10] G. J. De Castilho and M. A. Cremasco, "Comparison of downer and riser flows in a circulating bed by means of optical fiber probe signals measurements" Procedia Eng., vol. 42, pp. 295-302, 2012. https://doi.org/10.1016/j.proeng.2012.07.420

[11] A. Lanza, M. Islam, and H. De Lasa, "Particle cluster sizing in downer units. Applicable methodology across downer scale units," Powder Technol., vol. 316, pp. 198206, Jul. 2017. https://doi.org/10.1016/j.powtec.2016.11.035

[12] J. Liu, J. R. Grace, and X. Bi, "Novel multifunctional optical-fiber probe: I. Development and validation," AIChE Journal., vol. 49, no. 6, pp. 1405-1420, Jun. 2003. https://doi.org/10.1002/aic.690490607

[13] R. J. Santoro and C. R. Shaddix, "Laser Induced Incandescence," in Applied Combustion Diagnostics, New York: Taylor \& Francis, 2002, pp. 252-286. Available: URL

[14] A. B. S. Alquaity, E. Es-sebbar, and A. Farooq, "Sensitive and ultra-fast species detection using pulsed cavity ringdown spectroscopy," Opt. Express, vol. 23, no. 6, pp. 7217-7226, Mar. 2015. https://doi.org/10.1364/OE.23.007217

[15] R. K. Hanson, R. M. Spearrin, and C. S. Goldenstein, Spectroscopy and Optical Diagnostics for Gases. Springer International Publishing, 2016. https://doi.org/10.1007/978-3-319-23252-2

[16] E. F. Nasir and A. Farooq, "Intra-pulse laser absorption sensor with cavity enhancement for oxidation experiments in a rapid compression machine," Opt. Express, vol. 26, no. 11, pp. 14601-14609, May. 2018. https://doi.org/10.1364/OE.26.014601

[17] S. Lopez-Zamora, A. Alkhlel, and H. De Lasa, "Monitoring the progress of catalytic cracking for model compounds in the midinfrared (MIR) 3200--2800 $\mathrm{Cm}^{-1}$ range," Chem. Eng. Sci., vol. 192, pp. 788-802, Dec. 2018.

https://doi.org/10.1016/j.ces.2018.08.021

[18] H. De Lasa, "Riser simulator." Google Patents, 1992. https://patents.google.com/patent/US5102628 $\underline{\mathrm{A} / \mathrm{en}}$

[19] M. P. Helmsing, M. Makkee, and J. A. Moulijn, "Development of a bench scale FCC microriser," Deactivation and Testing of Hydrocarbon-Processing Catalysts Chapter 24, pp 322-339, 1996. https://doi.org/10.1021/bk-1996-0634.ch024

[20] X. Dupain, E. D. Gamas, R. Madon, C. P. Kelkar, M. Makkee, and J. A. Moulijn, 
In-Situ Characterization OF 1-Hexene Concentration with a Helium-Neon Laser In Thepresence of a Solid Catalyst

"Aromatic gas oil cracking under realistic FCC conditions in a microriser reactor," Fuel, vol. 82, no. 13, pp. 1559-1569, Sep. 2003. https://doi.org/10.1016/S00162361(03)00077-2

[21] M. A. Den Hollander, M. Wissink, M. Makkee, and J. A. Moulijn, "Gasoline conversion: reactivity towards cracking with equilibrated FCC and ZSM-5 catalysts," Appl. Catal. A Gen., vol. 223, no. 1-2, pp. 85102, Jan. 2002. https://doi.org/10.1016/S0926860X(01)00745-1

[22] A. Corma, C. Martínez, F. V Melo, L. Sauvanaud, and J. Y. Carriat, "A new continuous laboratory reactor for the study of catalytic cracking," Appl. Catal. A Gen., vol. 232, no. 1-2, pp. 247-263, Jun. 2002. https://doi.org/10.1016/S0926860X(02)00110-2

[23] A. Corma and L. Sauvanaud, "FCC testing at bench scale: New units, new processes, new feeds," Catal. today, vol. 218-219, pp. 107114, $\quad$ Dec. 2013. https://doi.org/10.1016/j.cattod.2013.03.038

[24] ASTM D3907 / D3907M-19, Standard Test Method for Testing Fluid Catalytic Cracking (FCC) Catalysts by Microactivity Test, ASTM International, West Conshohocken, PA, 2019. https://doi.org/10.1520/D3907_D3907M-19

[25] P. O’Connor and M. B. Hartkamp, “A microscale simulation test for Fluid Catalytic Cracking.," Characterization and Catalyst Development., Chapter 13 pp 135147, 1989.

https://doi.org/10.1021/bk-1989-0411.ch013

[26] T. Myrstad and H. Engan, "Testing of resid FCC catalysts in MAT," Appl. Catal. A Gen., vol. 171, no. 1, pp. 161-165, Jun. 1998. https://doi.org/10.1016/S0926860X(98)00100-8

[27] C. Delattre, M. Forissier, I. Pitault, D. Schweich, and J. R. Bernard, "Improvement of the microactivity test for kinetic and deactivation studies involved in catalytic cracking," Chem. Eng. Sci., vol. 56, no. 4, pp. 1337-1345, Feb. 2001. https://doi.org/10.1016/S00092509(00)00356-0

[28] D. Wallenstein, M. Seese, and X. Zhao, "A novel selectivity test for the evaluation of FCC catalysts," Appl. Catal. A Gen., vol. 231, no. 1-2, pp. 227-242, May. 2002. https://doi.org/10.1016/S0926860X(02)00052-2

[29] M. A. Den Hollander, M. Makkee, and J. A. Moulijn, "Coke formation in fluid catalytic cracking studied with the microriser," Catal. today, vol. 46, no. 1, pp. 27-35, Nov. 1998.
https://doi.org/10.1016/S0920-5861(98)00348$\underline{4}$

[30] M. T. Shah, R. P. Utikar, V. K. Pareek, G. M. Evans, and J. B. Joshi, "Computational fluid dynamic modelling of FCC riser: A review," Chem. Eng. Res. Des., vol. 111, pp. 403-448, Jul. 2016. https://doi.org/10.1016/j.cherd.2016.04.017

[31] Y. N. Kim, C. Wu, and Y. Cheng, "CFD simulation of hydrodynamics of gas--solid multiphase flow in downer reactors: revisited," Chem. Eng. Sci., vol. 66, no. 21, pp. 5357-5365, Nov. 2011. https://doi.org/10.1016/j.ces.2011.07.036

[32] G. C. Lopes, L. M. Rosa, M. Mori, J. R. Nunhez, and W. P. Martignoni, "Threedimensional modeling of fluid catalytic cracking industrial riser flow and reactions," Comput. Chem. Eng., vol. 35, no. 11, pp. 2159-2168, Nov. 2011.

https://doi.org/10.1016/j.compchemeng.2010. 12.014

[33] M. A. Ospina-Alarcón, A. B. Barientos-Ríos, M. O. Bustamante-Rua "Influence of the pulse wave in the stratification of high density particles in a JIG device," TecnoLógicas, vol. 19, no. 36, pp. 13-25, Jan. 2016.

https://doi.org/10.22430/22565337.585

[34] N. Gomez and A. Molina, "Analysis of the Particle Clustering Phenomenon in the Fluid Catalytic Cracking of Gasoil in a Downer Reactor," Chem. Eng. Technol., vol. 42, no. 6, pp. 1293-1303, Apr. 2019. https://doi.org/10.1002/ceat.201800463

[35] S. Al-Khattaf, J. A. Atias, K. Jarosch, and H. De Lasa, "Diffusion and catalytic cracking of 1, 3, 5 tri-iso-propyl-benzene in FCC catalysts," Chem. Eng. Sci., vol. 57, no. 22-23, pp. 4909-4920, Nov. 2002.

https://doi.org/10.1016/S00092509(02)00277-4

[36] Aspen Plus, "Aspen Plus user guide," Aspen Technol. Limited, Cambridge, USA, 2003. Available: URL

[37] Ansys Fluent ANSYS inc, "15.0 Theory Guide." (s/f). Available: URL

[38] J. A. Souza, J. V. C. Vargas, J. C. Ordonez, W. P. Martignoni, and O. F. von Meien, "Thermodynamic optimization of fluidized catalytic cracking (FCC) units," Int. J. Heat Mass Transf., vol. 54, no. 5-6, pp. 11871197, Feb. 2011. https://doi.org/10.1016/j.ijheatmasstransfer. 2010.10.034

[39] K. Ropelato, H. F. Meier, and M. A. Cremasco, "CFD study of gas - solid behavior in downer reactors: an Eulerian Eulerian approach," Powder Technol., vol. 154, no. 2-3, pp. 179-184, Jul. 2005. 
In-Situ Characterization OF 1-Hexene Concentration with a Helium-Neon Laser In Thepresence of a Solid Catalyst

[40] A. Lanza and H. de Lasa, "Scaling-up down flow reactors. CPFD simulations and model validation," Comput. Chem. Eng., vol. 101, pp. 226-242, Jun. 2017. https://doi.org/10.1016/j.compchemeng.2017. $\underline{02.034}$

[41] V. A. Petrov and V. Y. Reznik, "Measurement of the emissivity of quartz glass," High Temp.-High Press., vol. 4, no. 6, pp. 687-693, 1972. Available: URL

[42] S. A. Morsi and A. J. Alexander, "An investigation of particle trajectories in twophase flow systems," J. Fluid Mech., vol. 55, no. 2, pp. 193-208, Sep. 1972. https://doi.org/10.1017/S0022112072001806

[43] V. Ranade, Computational flow modeling for chemical reactor engineering, vol. 5. San Diego, USA: Academic Press, 2001. Available: URL

[44] D. F. Swinehart, "The beer-lambert law," $J$. Chem. Educ., vol. 39, no. 7, pp. 333. Jul. 1962. https://doi.org/10.1021/ed039p333

[45] A. E. Klingbeil, "Mid-IR laser absorption diagnostics for hydrocarbon vapor sensing in harsh environments," (PhD Thesis), Stanford University, Stanford, USA, 2007. Available: URL

[46] D. A. Skoog, D. M. West, F. James Holler, and S. R. crouch: Fundamentals of analytical chemistry. USA: Nelson Education, 2013.

\section{AUTHOR CONTRIBUTIONS}

D 1 Conceived and carried out the experiments as part of his thesis for his Master's degree in chemical engineering.

(D) 2 Supported the experiments and simulations by Mr. Lacayo.

Supported the experiments and simulations by Mr. Lacayo.

(D) 4 Corresponding author and thesis advisor for Mr. Lacayo's master's thesis. 